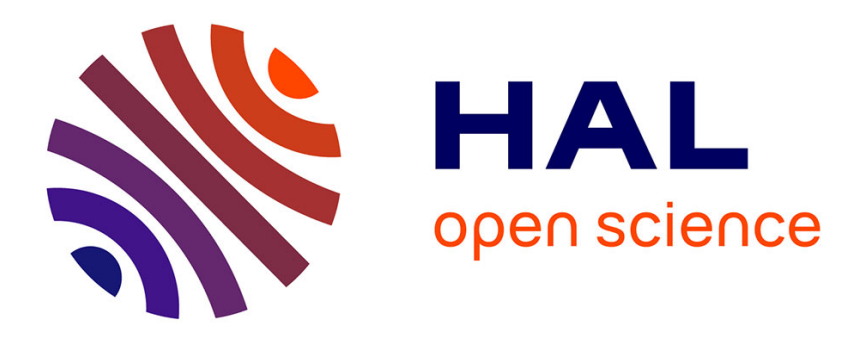

\title{
Organic fertilisation, soil quality and human health Eric Lichtfouse
}

\section{To cite this version:}

Eric Lichtfouse. Organic fertilisation, soil quality and human health. Springer, 9, pp.352, 2012, Sustainable Agriculture Reviews, 978-94-007-4112-6 print, 978-94-007-4113-3 online. 10.1007/978-94007-4113-3 . hal-00769695

\section{HAL Id: hal-00769695 https://hal.science/hal-00769695}

Submitted on 6 Jun 2020

HAL is a multi-disciplinary open access archive for the deposit and dissemination of scientific research documents, whether they are published or not. The documents may come from teaching and research institutions in France or abroad, or from public or private research centers.
L'archive ouverte pluridisciplinaire HAL, est destinée au dépôt et à la diffusion de documents scientifiques de niveau recherche, publiés ou non, émanant des établissements d'enseignement et de recherche français ou étrangers, des laboratoires publics ou privés. 


\title{
Sustainable Agriculture Reviews
}

\author{
Volume 9
}

Series Editor

Eric Lichtfouse

For further volumes:

http://www.springer.com/series/8380 
Sustainable Agriculture

http://dx.doi.org/10.1007/978-90-481-2666-8

Sustainable Agriculture, Volume 2

http://dx.doi.org/10.1007/978-94-007-0394-0

Organic Farming, Pest Control and Remediation of Soil Pollutants

http://dx.doi.org/10.1007/978-1-4020-9654-9

Climate Change, Intercropping, Pest Control and Beneficial Microorganisms http://dx.doi.org/10.1007/978-90-481-2716-0

Sociology, Organic Farming, Climate Change and Soil Science http://dx.doi.org/10.1007/978-90-481-3333-8

Genetic Engineering, Biofertilisation, Soil Quality and Organic farming http://dx.doi.org/10.1007/978-90-481-8741-6

Biodiversity, Biofuels, Agroforestry and Conservation Agriculture

http://dx.doi.org/10.1007/978-90-481-9513-8

Alternative Systems, Biotechnology, Drought Stress and Ecological Fertilisation http://dx.doi.org/10.1007/978-94-007-0186-1

Genetics, Biofuels and Local Farming Systems

http://dx.doi.org/10.1007/978-94-007-1521-9

Agroecology and Strategies for Climate Change

http://dx.doi.org/10.1007/978-94-007-1905-7

Organic Fertilisation, Soil Quality and Human Health

http://dx.doi.org/10.1007/978-94-007-4113-3

Environmental Chemistry. Green Chemistry and Pollutants in Ecosystems

http://dx.doi.org/10.1007/b137751

Environmental Chemistry for a Sustainable World

Volume 1. Nanotechnology and Health Risk

http://dx.doi.org/10.1007/978-94-007-2442-6

Environmental Chemistry for a Sustainable World

Volume 2. Remediation of Air and Water Pollution http://dx.doi.org/10.1007/978-94-007-2439-6

Rédiger pour être publié ! Conseils pratiques pour les scientifiques http://dx.doi.org/10.1007/978-2-287-99396-1

\section{Call for review articles}

Authors wishing to publish a review article in Sustainable Agriculture Reviews or Environmental Chemistry for a Sustainable World should contact the Editor.

E-mail: Eric.Lichtfouse@ dijon.inra.fr

*http://www.linkedin.com/pub/eric-lichtfouse/19/493/720, http://www.researcherid.com/ rid/F-4759-2011 
Eric Lichtfouse

Editor

Organic Fertilisation, Soil
Quality and Human Health

包 Springer 


\author{
Editor \\ Dr. Eric Lichtfouse \\ INRA, UMR1347 Agroécologie \\ 17 , rue Sully \\ 21000 Dijon \\ France
}

ISBN 2210-4410

ISBN 2210-4429 (electronic)

ISBN 978-94-007-4112-6

ISBN 978-94-007-4113-3 (eBook)

DOI 10.1007/978-94-007-4113-3

Springer Dordrecht Heidelberg New York London

Library of Congress Control Number: 2012937656

(C) Springer Science+Business Media B.V. 2012

This work is subject to copyright. All rights are reserved by the Publisher, whether the whole or part of the material is concerned, specifically the rights of translation, reprinting, reuse of illustrations, recitation, broadcasting, reproduction on microfilms or in any other physical way, and transmission or information storage and retrieval, electronic adaptation, computer software, or by similar or dissimilar methodology now known or hereafter developed. Exempted from this legal reservation are brief excerpts in connection with reviews or scholarly analysis or material supplied specifically for the purpose of being entered and executed on a computer system, for exclusive use by the purchaser of the work. Duplication of this publication or parts thereof is permitted only under the provisions of the Copyright Law of the Publisher's location, in its current version, and permission for use must always be obtained from Springer. Permissions for use may be obtained through RightsLink at the Copyright Clearance Center. Violations are liable to prosecution under the respective Copyright Law.

The use of general descriptive names, registered names, trademarks, service marks, etc. in this publication does not imply, even in the absence of a specific statement, that such names are exempt from the relevant protective laws and regulations and therefore free for general use.

While the advice and information in this book are believed to be true and accurate at the date of publication, neither the authors nor the editors nor the publisher can accept any legal responsibility for any errors or omissions that may be made. The publisher makes no warranty, express or implied, with respect to the material contained herein.

Printed on acid-free paper

Springer is part of Springer Science+Business Media (www.springer.com) 


\section{Contents}

Convergence or Divide in the Movement for Sustainable and Just Agriculture

Miguel A. Altieri

No-Till Agriculture in the USA

Jared Margulies

Organic Fertilizers in Sub-Saharan Farming Systems

Jonas N. Chianu, Justina N. Chianu, and Franklin Mairura

Biofuel Production Byproducts as Soil Amendments

Khaled D. Alotaibi and Jeff. J. Schoenau

Pseudomonas and other Microbes in Disease-Suppressive Soils.

Martina Kyselková and Yvan Moënne-Loccoz

Conservation Tillage Impact on Soil Aggregation,

Organic Matter Turnover and Biodiversity

Tek Bahadur Sapkota

Sustainable Agricultural NP Turnover

in the 27 European Countries

Péter Csathó and László Radimszky

Tomato Production for Human Health, Not Only for Food

Reza Ghorbani, Vahid Poozesh, and Surur Khorramdel

Jute Biology, Diversity, Cultivation, Pest Control, Fiber Production and Genetics

Susmita Maity, Sandipan Chowdhury, and Animesh K. Datta 
Decision Support Systems for Agrotechnology

Transfer. 263

Reshmi Sarkar

Plant Growth Retardants and Mineral Fertilisers for Cotton 301 Zakaria M. Sawan

Index 